\title{
Penerapan Model Auditory Intellectually Repetition (AIR) untuk Meningkatkan Kemampuan Berbicara Pada Mahasiswa
}

\author{
Nur Alfin Hidayati*, Agus Darmuki \\ IKIP PGRI Bojonegoro \\ *nikidanajwasalsabila@gmail.com
}

\begin{abstract}
This study aims to (1) increase interest in learning speaking skills using the Auditory, Intellectually, and Repetition Learning Model. (2) improve the learning outcomes of speaking skills using the Auditory, Intellectually, and Repetition Learning Model in class IB students of PBSI IKIP PGRI Bojonegoro Academic Year 2019/2020. This learning improvement study uses the principle of Classroom Action Research (CAR) conducted in 2 cycles. Each cycle consists of four stages, namely planning, implementing, observing, and reflecting. The subject of this research is the IB class of PBSI Study Program students, totaling 30 students. Data collection techniques using tests, observations, questionnaires, interviews, and documents. The data analysis technique of this study used an interactive analysis technique consisting of three components, namely grouping data, presenting data, and drawing conclusions. Based on the results of the study it can be concluded as follows: (1) Interest in learning speaking skills can be increased through the Auditory Learning Model, Intellectually, and Repetition; and (2) the application of Auditory, Intellectually, and Repetition learning models can improve speaking skills in IB class students of Indonesian Language and Literature Education Study Program IKIP PGRI Bojonegoro Academic Year 2019/2020.
\end{abstract}

Keywords: Ability; Speaking; Model; Auditory Intellectually Repetition Repetition.

\section{ABSTRAK}

Penelitian ini memiliki tujuan untuk (1) meningkatkan keaktifan dalam pembelajaran keterampilan berbicara menggunakan Model Pembelajaran Auditory, Intellectually, and Repetition. (2) meningkatkan hasil belajar keterampilan berbicara menggunakan Model Pembelajaran Auditory, Intellectually, and Repetition pada mahasiswa kelas IB Prodi PBSI IKIP PGRI Bojonegoro Tahun Akademik 2019/2020. Penelitian perbaikan pembelajaran ini menggunakan prinsip Penelitian Tindakan Kelas (PTK) yang dilakukan dalam 2 siklus. Setiap siklus terdiri dari empat tahap yaitu perencanaan, pelaksanaan, observasi, dan refleksi. Penelitian ini subjeknya adalah mahasiswa kelas IB Prodi PBSI yang berjumlah 30 mahasiswa. Teknik pengumpulan data menggunakan tes, observasi, wawancara, dan dokumen. Teknik analisis data penelitian ini menggunakan teknik analisis interaktif yang terdiri dari tiga komponen yaitu pengelompokkan data, penyajian data, dan penarikan simpulan. Berdasarkan hasil penelitian dapat disimpulkan sebagai berikut: (1) Minat pembelajaran keterampilan berbicara dapat meningkat melalui Model Pembelajaran Auditory, Intellectually, and Repetition; dan (2) penerapan model pembelajaran Auditory, Intellectually, and Repetition dapat meningkatkan keterampilan berbicara pada mahasiswa kelas IB Prodi Pendidikan Bahasa dan Sastra Indonesia IKIP PGRI Bojonegoro Tahun Akademik 2019/2020. Kata Kunci: Kemampuan; Berbicara; Model; Auditory Intellectually Repetition.

$$
\text { Submitted Apr 21, 20xx | Revised Nov 11, 20xx | Accepted Nov 28, 20xx }
$$

\section{Pendahuluan}

Dosen di dalam proses belajar mengajar dituntut memiliki kompetensi untuk mencapai tujuannya. Dosen untuk memiliki kompetensi tersebut harus mengembangkan diri sebaik mungkin, agar dapat memenuhi fungsinya yakni membina dan mengembangkan kemampuan mahasiswa secara profesional di dalam proses belajar mengajar khususnya mata kuliah Keterampilan Berbicara. Dosen dituntut harus senantiasa berpikir kreatif dalam setiap kegiatan pembelajaran.

Belajar merupakan suatu proses, tindakan, dan perilaku yang kompleks yang dialami oleh peserta didik (Hariyadi \& Darmuki, 2019: 281). Belajar dikatakan kompleks karena dipengaruhi oleh banyak faktor baik itu dari internal maupun dari eksternal peserta didik. Faktor internal dari peserta didik salah satunya adalah minat terhadap proses belajar. Minat adalah kekuatan mental yang mendorong adanya keinginan untuk mengarahkan sikap dan perilaku individu untuk aktif belajar 
(Darmuki dan Hidayati, 2019: 9). Faktor eksteral dari peserta didik seperti bahan materi, lingkungan belajar, sarana prasaran belajar dan lain-lain. Mahasiswa sebagai subjek yang terlibat dalam kegiatan belajar akan mengalami suatu proses belajar. Proses belajar ini ditandai dengan keaktifan mahasiswa di dalam pembelajaran. Keaktifan pembelajaran ini terlihat dari keterlibatan fisik maupun mental mahasiswa dalam proses pembelajaran. Menurut (Darmuki \& Hariyadi, 2019: 257), keaktifan yaitu suatu kegiatan/segala sesuatu yang menunjukkan adanya keterlibatan fisik maupun mental seseorang dalam aktivitas tertentu. Aktivitas tidak hanya ditentukan oleh aktivitas fisik semata, tetapi juga ditentukan oleh aktivitas non fisik seperti mental, intelektual dan emosional. Hal ini dalam konteks pembelajaran berbicara keaktifan dapat ditunjukkan dalam kegiatan secara lisan seperti menyampaikan pendapat, menanggapi, diskusi, mengajukan pertanyaan, memberi saran dan lain sebagainya.

Interaksi dan keaktifan dalam kegiatan pembelajaran sangat diperlukan karena pada prinsipnya belajar adalah melakukan (learning be doing) untuk dapat mengubah perilaku mahasiswa sebagai hasil belajar, karena tanpa interaksi dan keaktifan dalam kegiatan belajar tidak mungkin berjalan dengan baik (Elisa dkk., 2019: 157-158). Kegiatan ini terjadi karena interaksi individu dengan lingkungan dan bahan belajar. Kegiatan mahasiswa dapat ditingkatkan ketika dosen dapat menggunakan model pembelajaran yang tepat. Kegiatan belajar yang merupakan keterlibatan langsung mahasiswa (aktif) dalam proses pembelajaran yang dilalui untuk mencapai tujuan pembelajaran yang ingin dicapai. Dalam proses belajar mahasiswa akan menggunakan kemampuan mentalnya untuk mempelajari bahan materi. Penguasaan materi dalam bentuk kognitif, afektif dan psikomotorik itulah yang akan di evaluasi dalam bentuk hasil belajar.

Berbagai faktor dalam pembelajaran berpengaruh kepada hasil belajar mahasiswa yang optimal, salah satunya pemilihan model pembelajaran yang digunakan dosen. Selain itu penciptaan iklim belajar yang baik, serta peningkatan mutu sistem pembelajaran juga menjadi pertimbangan dosen. Hal-hal tersebut dilakukan dalam upaya meningkatkan mutu pembelajaran. Penyebab kurang baiknya hasil belajar mahasiswa khususnya mata kuliah Keterampilan Berbicara disebabkan oleh kurang tepatnya dosen dalam memilih metode/model belajar. Metode inilah yang sangat menentukan kegiatan peserta didik dalam belajar untuk memperoleh maksud yang diharapkan (Darmuki \& Hariyadi, 2019: 63). Agar tercipta suasana yang mendukung pelaksanaan pembelajaran yang melibatkan mahasiswa secara aktif, dosen harus membangun suasana kelas yang "hidup" sehingga seluruh mahasiswa dapat berinteraksi dengan baik. Dengan demikian diharapkan seluruh mahasiswa dapat mengembangkan potensinya dan meraih prestasi sebaik mungkin.

Berbicara adalah keterampilan yang diperoleh secara alamiah melalui proses kebiasaan menggunakannya dan latihan terus menerus (Darmuki dkk., 2019: 2). Berbicara merupakan sebuah cara berkomunikasi secara lisan antar individu atau kelompok untuk mencapai tujuan tertentu. Berbicara dilakukan dengan cara mengucapkan secara lisan berbagai kata dan dirangkai agar gagasan, ide, dan pikiran/ perasaan dapat tersampaikan kepada orang lain dengan tujuan tertentu. Mahasiswa dalam hal ini diharuskan untuk mampu memperlihatkan kemahirannya memilih dan menggunakan kata atau kalimat sehingga ide, pikiran, perasaan, dan gagasan yang dikomunikasikannya dapat diterima secara mudah oleh orang lain atau lawan bicaranya. Penguasaan bahasa berperan penting dalam berkomunikasi seseorang untuk mencapai tujuan tertentu. Keruntutan dan kejelasan berbicara seseorang akan memudahkan lawan bicara untuk bisa memahami dan mengerti apa yang disampaikan oleh pembicara. Keterampilan berbicara adalah kemampuan seseorang untuk menyampaikan ide, gagasan, pikiran, pesan atau informasi kepada orang lain dengan tujuan dapat dipahami lawan bicara (Darmuki dkk., 2018: 116).

Keterampilan berbicara merupakan keterampilan yang penting dikuasai oleh mahasiswa untuk berkomunikasi, menyampaikan pesan/informasi kepada orang lain dengan tujuan tertentu (Darmuki \& Hidayati., 2019: 9; Darmuki \& Hidayati, 2019: 121). Pembelajaran keterampilan berbicara sangat penting diajarkan kepada mahasiswa khususnya di Prodi PBSI karena ini merupakan kompetensi wajib 
yang harus dimiliki oleh mahasiswa calon guru (Darmuki dkk., 2017: 44). Keterampilan berbicara memiliki posisi yang strategis bagi mahasiswa karena melalui keterampilan berbicara yang baik dan runtut akan menggambarkan keruntutan berpikir mahasiswa serta menunjukkan keluasan pengetahuannya (Darmuki dkk., 2018: 115). Mahasiswa dituntut untuk dapat menguasai keterampilan berbicara dengan baik, runtut, dan lancar.

Kenyataannya setelah proses pembelajaran keterampilan berbicara selesai, kadang masih terdapat mahasiswa yang tidak dapat menguasainya dengan baik, yang tercermin dalam perolehan nilai evaluasi. Mereka memperoleh nilai yang belum mencapai batas Kriteria Ketuntasan Minimal (KKM), artinya mahasiswa yang bersangkutan tidak berhasil mencapai tujuan yang ditetapkan.

Dari hasil evaluasi di kelas IB Prodi PBSI IKIP PGRI Bojonegoro ditemukan bahwa, tingkat penguasaan materi keterampilan berbicara pertemuan pertama masih rendah. Hanya 5 dari 30 orang mahasiswa yang mendapat nilai di atas Kriteria Ketuntasan Minimal (KKM). Sedangkan nilai ketuntasan untuk mata kuliah keterampilan berbicara yang ditetapkan dosen adalah 75. Dengan hasil evaluasi tersebut maka harus dilakukan perbaikan pembelajaran. Berdasarkan kepada hasil analisis nilai yang diperoleh peserta didik terlihat jelas bahwa dalam upaya meningkatkan hasil belajar keterampilan berbicara diperlukan perbaikan pemilihan model dan lingkungan belajar. Dosen berperan penting dalam pelaksanaan pembelajaran yang berkelanjutan, sehingga sosok dosen harus menjadi penyebar informasi yang baik sekaligus berperan sebagai perencana, pelaksana, dan penilai pembelajaran.

Untuk meningkatkan hasil belajar peserta didik terhadap materi yang diajarkan, maka dilakukan perbaikan pembelajaran melalui Penelitian Tindakan Kelas (PTK). Kegiatan tersebut berfungsi memperbaiki pembelajaran serta mengembangkan diri secara profesional. Berdasarkan observasi awal terhadap pelaksanaan pembelajaran keterampilan berbicara pada mahasiswa kelas IB Prodi PBSI IKIP PGRI Bojonegoro, ditemukan beberapa masalah yang tidak mendukung pencapaian tujuan pembelajaran yakni: (1) Mahasiswa kurang aktif dan konsentrasi ketika dosen menjelaskan teori keterampilan berbicara atau mahasiswa sedang asyik ngobrol dengan teman; (2) Dosen terlalu banyak ceramah pada waktu menyampaikan materi, menyebabkan mahasiswa menjadi bosan dalam mengikuti mata kuliah keterampilan berbicara; (3) Motivasi mahasiswa sangat rendah untuk mengikuti mata kuliah keterampilan berbicara karena dianggap sebagai hal yang sulit dan tidak menyenangkan sehingga secara umum keaktifan mahasiswa dalam pembelajaran masih kurang.

Berdasarkan observasi awal di atas maka secara umum menunjukkan bahwa: (1) Dosen tidak dapat mengelola kelas dengan baik hal ini terlihat dari keaktifan mahasiswa dalam proses pembelajaran, sehingga kondisi tidak kondusif dan mahasiswa merasa tidak nyaman ketika pembelajaran berlangsung; (2) Metode yang digunakan dalam pembelajaran tidak sesuai dengan materi yang diajarkan sehingga suasana pembelajaran tidak berkembang (stuck); (3) Ada beberapa mahasiswa yang kurang aktif, dosen belum berhasil membuat mereka terlibat dalam pembelajaran secara aktif.

Banyak alternatif yang dapat digunakan oleh dosen untuk merangsang daya kreativitas mahasiswa dan memancing keterampilan mahasiswa untuk aktif berbicara, salah satunya dengan menggunakan model pembelajaran yang inovatif dan efektif merangsang kecerdasan berpikir. Salah satu model pembelajaran yang tepat untuk meningkatkan kemampuan berbicara mahasiswa yaitu model pembelajaran Auditory Intellectually Repetition (AIR). Menurut Hardiyanti dkk (2013: 520), model pembelajaran AIR merupakan model pembelajaran yang memprioritaskan keaktifan mahasiswa baik dalam menyimak, berbicara, menyampaikan ide/ pendapat secara lisan (Auditory), berlatih terampil kemampuan pemecahan masalah (Intellectually) serta memberikan pemahaman mahasiswa melalui pengulangan (Repetition) terkait bahan materi yang dipelajari yaitu berupa pendalaman, keluasan, pemantapan dengan cara mahasiswa diberi latihan melalui pemberian tugas/praktik dan kuis. Bukan hanya terampi dalam hal kemampuan memecahkan masalah dan pemahaman yang bisa diperoleh mahasiswa melainkan juga keterampilan berbicara atau komunikasi mahasiswa.

Model pembelajaran Auditory, Intellectually, Repetition (AIR). Auditory memiliki makna bahwa 
keaktifan peserta didik belajar haruslah dengan mendengarkan, menyimak, berbicara, presentasi, argumentasi, mengemukakan pendapat, dan menanggapi. Proses belajar dalam konteks ini lebih menekankan keaktifan mahasiswa sehingga proses pembelajaran terjadi interaksi multiarah antara dosen dengan mahasiswa, antara mahasiswa dengan mahasiwa yang lain, dan antara mahasiswa dengan bahan materi. Intellectually memiliki makna bahwa, keaktifan peserta didik belajar haruslah menggunakan kemampuan berpikir (minds-on), keaktifan peserta didik belajar haruslah dengan konsentrasi pikiran dan berlatih memaksimalkannya melalui bernalar, menyelidiki, mengidentifikasi, menemukan, mencipta, mengkonstruksi, memecahkan masalah, dan menerapkan. Proses belajar mahasiswa harus ditunjukkan dengan keaktifan yang memperlihatkan keterlibatan secara mental seperti berpikir, bernalar, mengaplikasikan dan mengembangkan keterampilan yang mengarah pada penguasaan kompetensi. Repetition memiliki makna pengulangan yang berarti pendalaman, perluasan, pemantapan dengan cara keaktifan peserta didik dilatih melalui pemberian tugas atau kuis. Dalam konteks pembelajaran berbicara ini Repetition mengarah pada praktik berbicara. Pembelajaran harus melibatkan fisik dan mental baik dari aspek kognitif, afektif, dan psikomotorik.

Alasan peneliti memilih Model AIR ini karena model ini menggunakan kepekaan pendengaran, kecerdasan, dan pengulangan dalam pembelajaran keterampilan berbicara. Oleh karena itu peneliti melakukan penelitian dengan judul Penerapan Model Auditory Intellectually Repetition (AIR) untuk Meningkatkan Kemampuan Berbicara pada Mahasiswa Kelas IB Prodi PBSI IKIP PGRI Bojonegoro Tahun Akademik 2019/2020.

Menurut Yennita dkk. (2011: 17), model pembelajaran AIR menganggap bahwa suatu pembelajaran akan efektif jika memperhatikan tiga hal, yaitu Auditory (mendengar), Intellectually (berpikir), dan Repetition (pengulangan). Belajar auditoris merupakan cara belajar standar bagi masayarakat (Huda, 2013). Meier (2000: 14) mendefinisikan kata "intelektual" menunjukkan apa yang dilakukan siswa dalam pikiran mereka secara internal ketika mereka menggunakan kecerdasan untuk merenungkan suatu pengalaman dan menciptakan hubungan, makna, rencana, dan nilai dari pengalaman tersebut. Repetition bermakna pengulangan. Dalam konteks pembelajaran, merujuk pada pendalaman, perluasan, dan pemantapan siswa dengan cara memberinya tugas atau kuis (Huda, 2013: 20). Hasil penelitian Ainia dkk. (2012: 91); Rohmayati dkk. (2013: 85); Burhan dkk., (2014: 11); (2014: ); Fitri \& Utomo (2016: 201); Pujiastutik (2016: 518), menyatakan bahwa pembelajaran dengan menggunakan model $A I R$ dapat memberi dampak pada mahasiswa untuk memiliki kemampuan yang lebih dalam pemahaman, kreativitas dan keaktifan dalam pembelajaran, kemampuan memecahkan masalah. Penelitian Yenita dkk.(2011: 81) tentang penggunaan pendekatan Auditory Intellectualy Repetition (AIR) dapat meningkatkan keterampilan sosial peserta didik dengan signifikan dan berdampak langsung pada peningkatan hasil belajar peserta didik.

Berdasarkan latar belakang di atas, maka rumusan masalah penelitian ini adalah: (1) Bagaimanakah peningkatan minat dalam pembelajaran keterampilan berbicara menggunakan model pembelajaran Auditory, Intellectually, Repetition (AIR) pada mahasiswa kelas IB Prodi PBSI IKIP PGRI Bojonegoro Tahun Akademik 2019/2020? (2) Bagaimanakah peningkatan hasil belajar kemampuan berbicara menggunakan model pembelajaran Auditory, Intellectually, Repetition (AIR) pada mahasiswa kelas IB Prodi PBSI IKIP PGRI Bojonegoro Tahun Akademik 2019/2020?.

\section{Metode Penelitian}

Jenis penelitian ini adalah jenis penelitian tindakan kelas, dengan pendekatan deskriptif kualitatif. Penilitan tindakan kelas ini terdiri dari dua siklus yaitu tindakan siklus 1 dan tindakan siklus 2. Masingmasing siklus terdiri dari perencaaan, pelaksanaan, pengamatan, dan refleksi. Subjek penelitian ini adalah mahasiswa Prodi Pendidikan Bahasa dan Sastra Indonesia IKIP PGRI Bojonegoro dengan jumlah 30 orang. Objek penelitian ini adalah proses pembelajaran mata kuliah Keterampilan Berbicara 
menggunakan model pembelajaran Auditory, Intellectually, Repetition (AIR) pada mahasiswa kelas IB Prodi PBSI IKIP PGRI Bojonegoro semester ganjil Tahun Akademik 2019/2020.

Tehnik pengumpulan data penelitian ini menggunakan wawancara, observasi, dokumentasi, dan tes. Teknik wawancara menggunakan panduan wawancara yang sudah disiapkan untuk mengumpulkan tentang respon terhadap proses pembelajaran menggunakan metode yang telah diterapkan oleh dosen. Teknik observasi menggunakan lembar observasi mahasiswa dan dosen untuk mengumpulkan data terkait dengan keaktifan mahasiswa dan dosen dalam proses belajar mengajar di kelas baik pada tindakan siklus 1 maupun tindakan siklus 2. Lembar observasi ini untuk mengukur keaktifan ini menggunakan 4 kriteria pengelompokkan yaitu 77-100\% kategori sangat tinggi, 56-76\% kategori tinggi, 41-55 \% kategori sedang, dan 0-40\% kategori rendah. Teknik dokumentasi berupa dokumen terkait dengan jurnal mengajar, RPS dan RPP dosen, serta dokumen lain yang mendukung data penelitian yang telah ada. Teknik pengumpulan data berupa tes digunakan untuk mengetahui hasil belajar dan keterampilan berbicara mahasiswa dalam pembelajaran yang dilakukan baik pada tindakan siklus 1 maupun tindakan siklus 2 .

Teknik analsis data ini menggunakan teknik analisis interaktif yang terdiri dari tiga komponen yaitu pengelompokkan data, penyajian data, dan penarikan simpulan. Data penelitian yang telah di dapat dari lapangan dikelompokkan sesuai dengan permasalahan selanjutnya dipilah-pilah data yang sesuai dengan yang dibutuhkan. Setelah data dikelompokkan kemudian data yang sudah sesuai dengan permasalahan disajikan untuk menjawab masing-masing rumusan masalah dan dianalisis sesuai kajian teori yang digunakan. Data yang sudah disajikan sesuai dengan permasalahan dan dikaji sesuai kajian teori kemudian disimpulkan berdasarkan temuan penelitian.

\section{Hasil dan Pembahasan}

Berbicara merupakan salah satu komunikasi langsung dalam bentuk lisan antara seseorang dengan orang lain atau kelompok lain. Keterampilan berbicara ini sangat penting untuk dikuasai oleh mahasiswa keguruan sebagai modal interaksi dalam proses pembelajaran. Pembelajaran keterampilan berbicara di perguruan tinggi masih mengalami banyak kendala yang dialami dosen di lapangan dengan berbagai permasalahan.

Kondisi mahasiswa kelas IB Prodi PBSI IKIP PGRI Bojonegoro dalam proses pembelajaran prasiklus masih rendah dan belum menunjukkan keterlibatan keaktifan mahasiswa. Dosen pada pembelajaran prasiklus menyampaikan pembelajaran secara klasikal dan menggunakan metode konvensional. Proses pembelajaran berlangsung kurang lancar dan kurang komunikatif. Interaksi antara dosen dengan mahasiswa dalam proses pembelajaran pun belum komunikatif. Keaktifan mahasiswa dalam proses pembelajaran masih kurang atau masih rendah. Berdasarkan pengamatan observer secara umum pada pembelajaran siklus 1 yang dilakukan telah bisa untuk meningkatkan keaktifan belajar kemampuan berbicara mahasiswa karena materi yang disampaikan dan metode yang digunakan sangat cocok untuk merangsang mahasiswa untuk berpendapat. Ini bisa dilihat ketika peneliti melemparkan masalah kepada mahasiswa dan menyuruh mahasiswa untuk memberikan pendapat terhadap masalah tersebut, keaktifan belajar ini juga didukung oleh hasil observasi keaktifan belajar mahasiswa dengan menggunakan metode AIR meningkat jika dibandingkan dengan hasil observasi sebelum tindakan yaitu keaktifan mahasiswa tergolong tinggi.

Hasil observasi pada tindakan siklus 1 menunjukkan bahwa tingkat keaktifan mahasiswa dalam belajar kemampuan berbicara pada tindakan siklus 1 secara umum dalam kategori "tinggi" karena berada diantara $70-85 \%$ ada sekitar 20 mahasiswa. Namun masih ada beberapa mahasiswa kategori 46-69\% "sedang". Hal itu disebabkan oleh pengelolaan pembelajaran di kelas pada tindakan siklus 1 yang belum maksimal. Namun kekurangan-kekurangan pada tindakan siklus 1 tersebut dapat diatasi pada tindakan siklus 2, sehingga keaktifan belajar mahasiswa pada tindakan siklus 2 meningkat. Hasil 
observasi pada tindakan siklus 2 keaktifan belajar mahasiswa meningkat dalam kategori "sangat tinggi" yaitu 17 mahasiswa, kategori "tinggi” 13 mahasiswa.

Tabel 1. Hasil observasi Skor Pra-Siklus, Siklus 1, Siklus 2

\begin{tabular}{llccc}
\hline Skor Angket & Kategori & Pra Siklus & Siklus 1 & Siklus 2 \\
\hline $86-100$ & Sangat Tinggi & 0 & 1 & 17 \\
$70-85$ & Tinggi & 6 & 20 & 13 \\
$46-69$ & sedang & 24 & 9 & 0 \\
$>45$ & Kurang & 0 & 0 & 0 \\
\hline
\end{tabular}

Demikan juga dengan keaktifan dosen, mengalami peningkatan dari tindakan siklus 1 yang dalam kategori "tinggi". Pada tindakan siklus 2 keaktifan dosen meningkat dikategori "sangat tinggi" dalam hal ini dosen memberikan intruksi yang jelas dan memberikan motivasi yang mengarah pada keaktifan mahasiswa.

Salah satu cara agar aktif dalam proses pembelajaran mahasiswa harus dikondisikan terlibat interaksi secara fisik maupun mental dalam pembelajaran dengan baik. Keterlibatan itu dalam bentuk menyimak dengan penuh pemahaman (berpikir), menyampaikan pendapat, memberikan saran, berlatih berbicara dalam diskusi, lalu mempraktikkannya. Hal ini sesuai pendapat Elisa dkk. (2019: 157-158) Interaksi dan keaktifan dalam kegiatan pembelajaran sangat diperlukan karena pada prinsipnya belajar adalah melakukan (learning be doing) untuk dapat mengubah perilaku mahasiswa sebagai hasil belajar, karena tanpa interaksi dan keaktifan dalam kegiatan belajar tidak mungkin berjalan dengan baik dan optimal. Keaktifan mahasiswa dalam proses pembelajaran yang optimal menjadikan pembelajaran lebih bermakna dan menyenangkan karena mahasiswa betul-betul merasa pembelajaran itu bagian dari dirinya. Berdasarkan nilai hasil tes pra siklus, tindakan siklus 1 dan tindakan siklus 2 terjadi peningkatan baik dari segi pengetahuan maupun dari segi keterampilan mahasiswa pada mata kuliah Keterampilan Berbicara, seperti pada tabel 2.

Tabel 2. Hasil Skor Pra-Siklus, Siklus 1, Siklus 2

\begin{tabular}{clccc}
\hline No & Kategori & Pra & Siklus & Siklus \\
& & Siklus & $\mathbf{1}$ & $\mathbf{2}$ \\
\hline $\mathbf{1}$ & Pengetahuan & 64 & 75 & 84 \\
$\mathbf{2}$ & Keterampilan & 68 & 78 & 88 \\
\hline
\end{tabular}
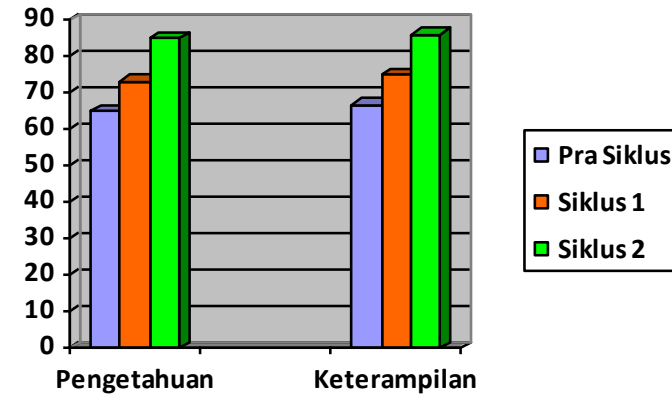

Gambar 3: Histogram Nilai Mahasiswa Pra-siklus, Siklus I, Siklus II

Ditinjau secara global terdapat peningkatan rata-rata nilai mahasiswa dalam setiap siklusnya, baik nilai pengetahuan maupun keterampilan. Dalam grafik tersebut nampak bahwa nilai pengetahuan lebih rendah daripada nilai keterampilan, namun pada siklus ke-II perbedaan itu sudah semakin tipis.

Cara dosen dalam menyampaikan materi pada saat proses belajar mengajar berpengaruh kepada hasil belajar mahasiswa. Hal ini terbukti dengan penggunaan video yang berhasil meningkatkan 
kemampuan mahasiswa dalam keterampilan berbicara. Sesuai dengan temuan Darmuki \& Hidayati (2019: 126)

Berdasarkan data tersebut diketahui bahwa, prestasi belajar mahasiswa dengan penerapan model pembelajaran Auditory, Intellectually, Repetition (AIR) menggunakan media video menunjukkan bahwa kemampuan berbicara meningkat. Dari pra-siklus, siklus I sampai dengan siklus II yaitu rata-rata nilai pengetahuan pra-siklus sebesar 64; siklus I memiliki rata-rata sebesar 68; dan siklus II sebesar 84 . Sedangkan rata-rata nilai keterampilan yaitu 68 pada tahap pra-siklus, 78 pada siklus I, dan 88 pada siklus II. Hal ini menjadi bukti bahwa, pemilihan dan penggunaan metode pembelajaran yang tepat dapat meningkatkan prestasi mahasiswa (Darmuki dkk., 2017: 79). Dalam hal ini model pembelajaran Auditory, Intellectually, Repetition (AIR) dilaksanakan dengan menggunakan media video. Selain itu, hal yang tidak kalah pentingnya adalah kesadaran para mahasiswa akan tanggung jawabnya yakni belajar. Kesadaran ini harus muncul dalam diri setiap mahasiswa untuk selalu mau belajar. Belajar sepanjang hayat menjadi kesadaran personal atas tanggungjawab untuk belajar maju dan berkembang meningkatkan kualitas diri serta selalu memperbaharui perkembangan pengetahuannya, keterampilannya selalu dilatih melalui pengalaman belajarnya agar tidak usang oleh perkembangan zaman yang berkembang lebih cepat dari pada ilmu pengetahuan dan keterampilan itu sendiri.

\section{Kesimpulan}

Berdasarkan hasil penelitian tindakan kelas yang telah dilakukan, maka dapat diambil simpulan sebagai berikut: (1) Penerapan model pembelajaran AIR dapat meningkatkan keaktifan pembelajaran keterampilan berbicara pada mahasiswa di kelas IB Prodi PBSI IKIP PGRI Bojonegoro Tahun Akademik 2019/2020. Hal ini diketahui dari besarnya nilai pengetahuan yang diperoleh para mahasiswa. Nilai pra-siklus sebesar 64; siklus I menjadi 75; dan siklus II sebesar 84; (2) Penggunaan atau pemanfaatan media video dalam pembelajaran keterampilan berbicara dapat meningkatkan nilai keterampilan para mahasiswa. Hal tersebut dapat diketahui dengan naiknya rata-rata nilai keterampilan para mahasiswa dari pra-siklus sebesar 68; siklus I menjadi 78; dan siklus II sebesar 88.

\section{Daftar Pustaka}

Ainia, Q., N. Kurniasih, \& M. Sapti. (2012). Eksperimentasi Model Pembelajaran Auditory Intellectually Repetition (AIR) Terhadap Prestasi Belajar Matematika Ditinjau dari Karakter Belajar Siswa Kelas VII SMP Negeri Se-Kecamatan Kaligesing Tahun 2011/2012. Prosiding Seminar Nasional. Semarang: Program Studi Pendidikan Matematika FMIPA Universitas Negeri Yogyakarta.

Burhan, A. V., Suherman, \& Mirna. (2014). Penerapan Model Pembelajaran AIR Pada Pembelajaran Matematika Siswa Kelas VIII SMPN 18 Padang, 3(1), 6-11.

Fitri, S., \& Utomo, R. B. (2016). Pengaruh Model Pembelajaran Auditory, Intellectually, and Repetition Terhadap Kemampuan Pemahaman Konsep. Jurnal E-DuMath, 2(2), 193-201.

Darmuki, A. \& Ahmad Hariyadi. (2019). Eksperimentasi Model Pembelajaran Jucama Ditinjau Dari Gaya Belajar Terhadap Prestasi Belajar Mahasiswa Mata Kuliah Berbicara Di Prodi PBSI IKIP PGRI Bojonegoro. Kredo. 3(1), 62-72.

Darmuki, A. \& Hidayati N.A. (2019). An Investigation of The Cooperative Learning Using Audio Visual Media in Speaking Skill Subject. ICSTI. 121-126.

Darmuki, A. \& Hidayati, N.A. (2019). Peningkatan Kemampuan Berbicara Menggunakan Metode Kooperatif Tipe NHT pada Mahasiswa Tingkat I-A Prodi PBSI IKIP PGRI Bojonegoro Tahun Akademik 2018/2019. Jurnal Pendidikan Edutama. Vol. 6(2), hlm 9-18.

Darmuki, A., Ahmad Hariyadi. (2019). Peningkatan Keterampilan Berbicara Menggunakan Metode Kooperatif Tipe Jigsaw pada Mahasiswa PBSI Tingkat IB IKIP PGRI Bojonegoro Tahun Akademik 2018/2019. Kredo. 2(2), 256-267. 
Darmuki, A., Andayani, Joko Nurkamto, Kundharu Saddhono. (2017). Cooperative, Synectics, and CTL Learning Models Toward Speaking Ability Viewd from Students Motivation. Proceeding International Conference on Intellectuals'Global Responsibility (ASSEHR). Vol. 125, 75-79.

Darmuki, A., Andayani, Joko Nurkamto, Kundharu Saddhono. (2017). Evaluating InformationProcessing-Based Learning Cooperative Model on Speaking Skill Course. Journal of Language Teaching and Reasearch. 8(1) pp. 44-51.

Darmuki, A., Andayani, Joko Nurkamto, Kundharu Saddhono. (2018). The Development and Evaluation of Speaking Learning Model by Cooperative Approach. International Joumal of Instruction. 11(2), 115-128.

Darmuki, A., Ahmad Hariyadi, Nur Alfin Hidayati. (2019). Developing Beach Ball Group Investigations Cooperative. International Conferences Seword Fresh, 1-7.

Elisa L., Hardiyanto \& Yanti Fitria. (2019). Application of Learning Model Auditory, Intellectually, Repetition (AIR) To Increase Student Activity and Learning Outcomes In 2013 Curriculum Integrated Thematic Learning in Class IV SDN 06 Hand of Padang. International Journal of Educational Dynamics. 1(2),156-162.

Hariyadi, A. \& Darmuki, A. (2019). Prestasi dan Motivasi Belajar dengan Konsep Diri. Prosiding Seminar Nasional Penguatan Muatan Lokal Babasa Daerah sebagai Pondasi Pendidikan Karakter Generasi Milenial. PGSD UMK 2019, 280-286.

Hardiyanti, I.G.A.D. dkk. (2013). Pengaruh Penggunaan Model Pembelajaran Auditory Intellectually Repetition (AIR) Terhadap Hasil Belajar Siswa Kelas X. Kumpulan Artikel Mahasiswa Pendidikan Teknik Informatika (KARMAPATI), 2(4), 519-524.

Huda, M. (2013). Model-Model Pengajaran Dan Pembelajaran. Yogyakarta: Pustaka Pelajar.dan daya ingat yang kuat.

Meier, Dave. (2000). Accelerated Leaming Handbook. Bandung: Kaifa.

Pujiastutik, H. (2016). Penerapan Model Pembelajaran AIR ( Auditory, Intellectualy , Repetition ) untuk Meningkatkan Hasil Belajar Mahasiswa Mata Kuliah Belajar Pembelajaran Application of Learning Model AIR (Auditory, Intellectualy, Repetition) to Improve Student Learning. Proceding Biology Education Conference, 13(1), 515-518.

Rohmayati, A., N. Kurniasih \& R. Y. Purwoko. (2013). Eksperimentasi Model Pembelajaran Auditory Intellectually Repetition Dan Reciprocal Teaching Ditinjau Dari Kemampuan Berpikir Kritis. FMIPA Universitas Muhammadiyah Purworejo, Purworejo.

Yennita, M. Rahmad, \& Sugino. (2011). Peningkatan Keterampilan Sosial Siswa Melalui Penerapan Pendekatan Auditory Intellectualy Repetition Dalam Pembelajaran Fisika. PMIPA FKIP Universitas Riau, Pekanbaru. 